\title{
P348: Medical emergencies in national hospital of Lamorde, Niger
}

\author{
H Djibo ${ }^{*}$ KK Issa, M Arzika, Al Toure \\ From 2nd International Conference on Prevention and Infection Control (ICPIC 2013) \\ Geneva, Switzerland. 25-28 June 2013
}

\section{Objectives}

The emergency department of the National Hospital Lamorde is the venue for all patients whose care has not been programmed. But its use as a gateway to the health care system generates a space which decreases efficiency for real emergencies. Identifying the causes of malfunctions is essential to start making provision for improved organization and provision of emergency services.

\section{Methods}

We conducted a prospective cross-sectional study in the emergency department of the National Hospital Lamordé from 1 January to 31 December 2005. The survey made it possible to follow, 780 patients treated for medical and pediatric problems using individual records. Our variables are socio-demographic, clinical, paraclinical and therapeutic.

\section{Results}

The mean age of patients was 24.8 years with a female predominance of $57 \%, 69.2 \%$ of visits are made to the hours of service the average waiting time is $20 \mathrm{~min}$ consultations with $90 \mathrm{~min}$ peak rush hour, $100 \%$ of transport were not medicalized and $97.6 \%$ were provided by untrained people, $76 \%$ of patients have made a self-reference, the majority or $72 \%$ of consultations were performed by students, $44 \%$ of cases one needs urgent care, pediatric emergencies represent $25.4 \%$ of admissions, malaria is the leading cause of under observation with $62.85 \%$ of cases, the completion rate effective diagnostic tests is $46.6 \%$. These results come after a mean waiting time of $90 \mathrm{~min}$, the average waiting time is $30 \mathrm{~min}$ care; $95.9 \%$ of patients made comments emergencies had a favorable, the mortality rate was $41 \%$. Coma and PCBs are the primary causes

National Hospital of Niamey, Niamey, Niger each with $25 \%$ of cases and malaria is the leading cause of mortality of pediatric cases with $27.14 \%$ of cases.

\section{Conclusion}

The finding results inspired our recommendations for improving the organization, the service efficiency and quality of structures by conventional standards.

\section{Disclosure of interest}

None declared.

Published: 20 June 2013

doi:10.1186/2047-2994-2-S1-P348

Cite this article as: Djibo et al:: P348: Medical emergencies in national hospital of Lamorde, Niger. Antimicrobial Resistance and Infection Control 2013 2(Suppl 1):P348.
Submit your next manuscript to BioMed Central and take full advantage of:

- Convenient online submission

- Thorough peer review

- No space constraints or color figure charges

- Immediate publication on acceptance

- Inclusion in PubMed, CAS, Scopus and Google Scholar

- Research which is freely available for redistribution
() Bïomed Central
(C) 2013 Djibo et al; licensee BioMed Central Ltd. This is an Open Access article distributed under the terms of the Creative Commons Attribution License (http://creativecommons.org/licenses/by/2.0), which permits unrestricted use, distribution, and reproduction in any medium, provided the original work is properly cited. 